\title{
KOMPARASI METODE INTERPOLASI UNTUK SISTEM PENGENALAN SEL DARAH PUTIH
}

\author{
Lina $^{1}$, Kelly Anthony ${ }^{2}$ \\ 1,2 Teknologi Informasi, Universitas Tarumanegara, Jakarta Indonesia \\ E-Mail:1 lina@untar.ac.id, ${ }^{2}$ keley_kel@live.com
}

\begin{abstract}
The over time role of technology becomes very important. That is because the function of technology is to facilitate human work. Because human needs are increasingly complex, technological developments are created in such a way as to meet human needs. The experts in the medical field are currently very dependent on technology to do their jobs, in order to obtain effective and efficient results. Application system designed aims to help experts in the medical field to diagnose diseases through introduction to white blood cell types. The recognition system was developed using the Nearest Feature Line (NFL) method. In this NFL method, characteristic lines are formed using the method of linear interpolation, linear spline, quadratic spline, and cubic spline. Aside from introducing an introduction system, this paper also discusses comparisons between interpolation methods to form characteristic lines. The test was carried out using FTI Untar Pattern Recognition laboratory blood cell data. The test results show that the formation of characteristic lines using the linear interpolation method provides better recognition results compared to the spline interpolation method.
\end{abstract}

Keywords: Nearest Feature Line, Linear Interpolation, Spline Interpolation.

\begin{abstract}
ABSTRAK
Seiring berjalannya waktu peran teknologi menjadi sangat penting. Hal itu disebabkan karena fungsi dari teknologi yaitu mempermudah perkerjaan manusia. Karena kebutuhan manusia semakin kompleks, maka perkembangan teknologi diciptakan sedemikian rupa untuk memenuhi kebutuhan manusia. Para tenaga ahli dalam bidang kedokteran pun saat ini sangat bergantung pada teknologi dalam melakukan pekerjaannya, guna memperoleh hasil yang efektif dan efisien. Sistem aplikasi yang dirancang bertujuan untuk membantu ahli dalam bidang medis untuk mendiagnosis penyakit melalui pengenalan terhadap jenis sel darah putih. Sistem pengenalan yang dikembangkan menggunakan metode Nearest Feature Line (NFL). Dalam metode NFL ini, garis ciri dibentuk menggunakan metode interpolasi linier, spline linier, spline kuadratik, dan spline kubik. Selain melakukan sistem pengenalan, makalah ini juga membahas perbandingan antara metode interpolasi untuk membentuk garis ciri. Pengujian dilakukan dengan menggunakan data sel darah laboratorium Pattern Recognition FTI Untar. Hasil pengujian menunjukkan bahwa pembentukan garis ciri menggunakan metode interpolasi linier memberikan hasil pengenalan yang lebih baik dibandingkan dengan metode interpolasi spline.
\end{abstract}

Kata Kunci: Nearest Feature Line, Interpolasi Linier, Interpolasi Spline.

\section{PENDAHULUAN}

Seiring berjalannya waktu peran teknologi menjadi sangat penting. Hal itu disebabkan karena fungsi dari teknologi yaitu mempermudah perkerjaan manusia. Karena kebutuhan manusia semakin kompleks, maka perkembangan teknologi diciptakan sedemikian rupa untuk memenuhi kebutuhan manusia. Para tenaga ahli dalam bidang kedokteran pun saat ini sangat bergantung pada teknologi dalam melakukan pekerjaannya, guna memperoleh hasil yang efektif dan efisien.

Darah adalah cairan yang terdapat pada semua makhluk hidup (kecuali tumbuhan) tingkat tinggi yang berfungsi untuk mengangkut oksigen yang diperlukan oleh sel-sel diseluruh tubuh (Hoffbrand, A.V Pettit, J.E and Moss, 2008) (Kiernan, 1999). Dalam tubuh manusia darah juga berfungsi menyuplai jaringan tubuh dengan nutrisi, mengangkut zat-zat sisa metabolisme, dan mengandung berbagai bahan penyusun sistem imun yang bertujuan mempertahankan tubuh dari berbagai penyakit.

Citra adalah representasi (gambaran), kemiripan, atau imitasi dari suatu objek. Citra sendiri terbagi menjadi 2, yaitu citra digital dan citra analog. Citra analog adalah citra yang bersifat kontinu seperti foto sinar X, hasil CT Scan. Sedangan citra digital adalah citra yang dapat diolah oleh komputer. Teknologi dasar untuk menciptakan dan menampilkan warna pada citra digital berdasarkan pada penelitian bahwa sebuah 
warna merupakan kombinasi dari tiga warna dasar, yaitu merah, hijau dan biru (Red, Green, Blue RGB) (Chapra, 2005).

Permasalahan umum dalam bidang kedokteran adalah dalam mendiagnosa suatu penyakit, dimana membutuhkan suatu keakuratan. Banyak cara dalam mendiagnosa suatu penyakit, salah satunya adalah dengan melihat perubahan yang terjadi dalam darah. Sebenarnya laboratorium telah memiliki metode untuk melakukan perhitungan sel darah, yaitu metode manual dan menggunakan mesin hitung (blood cell counter). Pemeriksaan dengan metode manual sendiri membutuhkan waktu yang sangat lama dan tidak menunjukkan ketelitian serta ketepatan yang baik. Sedangkan untuk mesin hitung sendiri sudah terbilang sangat baik dalam melakukan perhitungan karena hasilnya yang sangat akurat dan efisien, namun mesin ini hanya terdapat pada laboratorium besar saja karena harganya yang tergolong mahal.

Oleh karena itu, diperlukan sebuah program yang dapat mengatasi masalah tersebut. Program yang akan dibuat disini masih terbatas pada pengenalan sel darah putih. Dalam pembuatan program ini metode yang digunakan adalah Principal Component Analysis, Nearest Feature Line dengan Interpolasi Linier dan Spline, dan Euclidean Distance. Principal Component Analysis (Karhunen-Loeve) merupakan metode untuk mereduksi sebuah citra digital sehingga dalam waktu komputasi akan lebih cepat (Kusumoputro, 2003)

Setelah citra direduksi kemudian citra di representasikan pada ruang eigen sehingga di dapatkan titik cirinya. Kemudian dengan metode Nearest Feature Line titik ciri yang telah didapat digeneralisasikan menjadi garis ciri atau feature line. Dilakukannya pembuatan garis pada ruang eigen bertujuan untuk menambah informasi variasi ciri dari kelas objek tanpa harus menambahkan titik ciri (Li, 1999). Selanjutnya untuk pengenalan digunakan metode Euclidean distance.

\section{METODE PENELITIAN}

\section{Principal Component Analysis}

Principal Component Analysis (PCA) adalah suatu metode yang digunakan untuk mengindentifikasi pola pada sebuah data, dan merepresentasikan data tersebut berdasarkan kemiripan dan perbedaan ke dalam ruang tertentu. Kelebihan dari PCA adalah dapat mereduksi dimensi citra, sehingga mempercepat dalam proses komputasi dan juga citra yang direduksi tersebut tetap menyimpan informasi penting walau banyak dimensinya telah hilang (Sani, 2018).

Cara kerja yang dilakukan oleh PCA yaitu.
1. Ambil suatu matriks $\boldsymbol{z}_{\boldsymbol{n}}$ dari $\boldsymbol{M}$ citra latih, dimana setiap matriks citra disusun dalam bentuk vektor dengan dimensi $\boldsymbol{d}$ x 1 .

2. Hitung vektor rata-rata $\boldsymbol{\mu}_{z}$ dengan persamaan:

$$
\mu_{z}=\frac{1}{M} \sum_{n=1}^{M} z_{n}
$$

Keterangan:

$\boldsymbol{\mu}_{\mathbf{z}}=$ Nilai rata-rata dari vektor darah

$\boldsymbol{M}$ = Banyaknya citra latih

$z_{n}=$ Nilai vektor dari citra wajah ke-n

3. Hitung matriks kovarian $\boldsymbol{C}_{\boldsymbol{z}}$ dengan persamaan:

$$
C_{z}=\frac{1}{M} \sum_{n=1}^{M}\left(z_{n}-\mu_{z}\right)\left(z_{n}-\mu_{z}\right)^{T}
$$

Keterangan:

$\boldsymbol{C}_{z}=$ Matriks kovarian

$\boldsymbol{T}=$ Matriks Transpose

4. Hitung nilai eigen dan vektor eigen dari matriks kovarian $\boldsymbol{C}_{z}$.

$$
\begin{aligned}
& \operatorname{Det}\left(\lambda . I-C_{z}\right)=0 \\
& C_{z} \cdot e_{z}=\lambda_{z} \cdot e_{z} \ldots \ldots .
\end{aligned}
$$

Keterangan:

$\Lambda_{z}=$ Nilai eigen dari $\boldsymbol{C}_{z}$

$I=$ Matriks Identitas

$\boldsymbol{e}_{z}=$ Vektor eigen dari $\boldsymbol{C}_{z}$

Setelah nilai eigen dan vektor eigen didapat, kemudian vektor-vektor eigen dalam matriks $\boldsymbol{e}_{z}$ disusun dari nilai terbesar sampai terkecil. Pengurutan ini bertujuan untuk memudahkan proses reduksi dimensi matriks transformasi. Proses reduksi dimensi ini dilakukan dengan cara mengabaikan vektor eigen yang bernilai kecil.

5. Hitung dan tentukan proporsi kumulatif nilai eigen yang bertujuan untuk menentukan nilai eigen yang akan digunakan untuk proses reduksi, berdasarkan persamaan:

$$
\boldsymbol{\alpha}^{k}=\frac{\left(\sum_{i=1}^{k} \lambda_{i}\right)}{\left(\sum_{j=1}^{Z} \lambda_{j}\right)}
$$

Keterangan:

$\boldsymbol{\alpha}^{k}=$ Proporsi kumulatif dari nilai eigen

6. Reduksi dimensi citra yang kemudian digunakan untuk memetakan sekumpulan vektor $\boldsymbol{z}_{\boldsymbol{n}}$ menjadi sekumpulan vektor $\boldsymbol{Y}_{\boldsymbol{n}}$ di dalam ruang eigen, menggunakan persamaan:

$$
Y_{n}=E_{k}^{T}\left(z_{n}-\mu_{z}\right)
$$


Keterangan:

$\boldsymbol{Y}_{\boldsymbol{n}}=$ Nilai vektor citra ke- $n$

$\boldsymbol{E}_{k}^{T}=$ Matriks transformasi dengan $k$ vektor eigen

Masing-masing vektor yang terdapat pada matriks $\boldsymbol{Y}_{\boldsymbol{n}}$ inilah yang satu per satu ditransformasikan ke dalam ruang eigen dan akan dipakai sebagai titik ciri.

\section{Nearest Feature Line}

Setelah nilai vektor citra dipetakan atau ditransformasikan menjadi titik ciri ke dalam ruang eigen, masing-masing titik ciri tersebut akan digeneralisasi menjadi garis ciri atau feature line dengan menghubungkan titik - titik ciri dalam kelas objek yang sama (Kusumoputro, 2003). Dilakukannya pembuatan garis pada ruang eigen bertujuan untuk menambah informasi variasi ciri dari kelas objek tanpa harus menambahkan titik ciri dengan citra baru. Selain itu pembuatan garis ciri pada ruang eigen juga lebih mudah dilakukan daripada membuat normalisasi dan reduksi dimensi untuk memperoleh variasi ciri.

Setelah tahap pelatihan selesai, data citra uji akan dimasukan dan dilakukan proses ektraksi PCA untuk mendapatkan titik ujinya dengan hanya melakukan proses reduksi dengan menggunakan nilai eigen dan vektor eigen dari proses pelatihan yang telah dilakukan sebelumnya, dan kemudian setelah itu titik uji ditransformasikan ke dalam ruang eigen. Titik uji ini merupakan titik baru dalam ruang eigen yang akan diberi nama titik $\boldsymbol{u}$.

Selanjutnya, setiap titik dalam kelas objek yang sama akan dihubungkan dengan Interpolasi Linier dan Interpolasi Spline untuk membentuk garis cirinya. Titik $\boldsymbol{u}$ akan diproyeksikan tegak lurus terhadap semua garis ciri yang dibentuk melalui vektor pelatihan.

\section{Interpolasi Linier}

Interpolasi dalam bidang matematika, khususnya metode numerik, interpolasi merupakan metode untuk menghasilkan titik data baru pada rentang sebuah data yang telah diketahui. Dalam bidang teknik atau ilmu pengetahuan, interpolasi digunakan sebagai pembentuk fungsi pendekatan yang dapat memenuhi titik sebuah data. Interpolasi sendiri mempunyai beberapa jenis yaitu interpolasi linier, interpolasi polinomial, dan interpolasi spline.

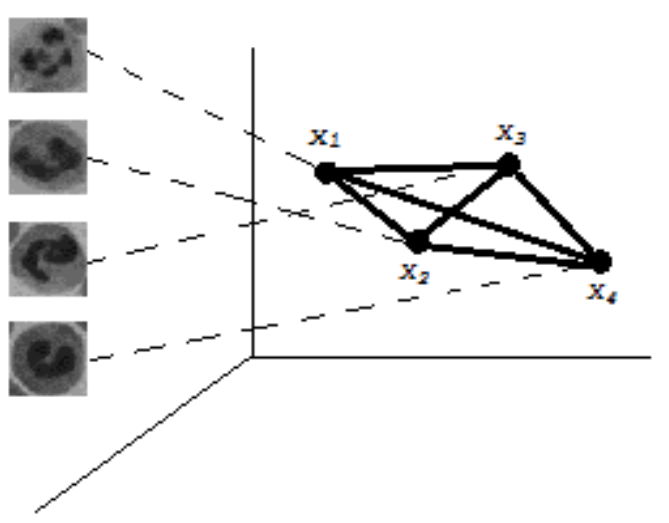

Sumber : (K. A. Lina, 2019)

Gambar 2. Interpolasi Linier

Interpolasi linier adalah bentuk interpolasi yang paling sederhana dimana hanya menentukan titik antara dua buah titik $\left(\mathrm{x}_{1}\right.$ dan $\left.\mathrm{x}_{2}\right)$ dengan menggunakan garis lurus (Weisstein, 2017). Gambar 2 menunjukkan contoh interpolasi linier dalam ruang Eigen. Untuk menghitung jarak tersebut menggunakan persamaan (B. K. Lina, 2004):

$$
p=x_{1}+\mu\left(x_{2}-x_{1}\right)
$$

dengan $\mu$ adalah parameter posisi,yang karena tegak lurus maka dapat dihitung sebagai dot product dengan persamaan[1]:

$$
\mu=\left(x-x_{1}\right) \cdot \frac{x_{2}-x_{1}}{x_{2}-x_{1}} \cdot\left(x_{2}-x_{1}\right) \ldots \ldots
$$

Umumnya, semakin kecil interval antara titik data, tafsiran akan semakin baik.

\section{Interpolasi Spline}

Interpolasi spline adalah fungsi polinomial dengan turunan memenuhi kendala kekontinuan tertentu. Interpolasi spline sendiri menggunakan polinomial berderajat rendah pada tiap intervalnya sehingga didapatkan grafik yang halus. Tidak seperti polinomial yang lain, interpolasi spline menghasilkan kesalahan yang rendah dan menghasilkan kurva yang lebih halus.

\section{Spline Linier}

Gambar 3 menunjukkan contoh interpolasi spline linier dalam ruang Eigen. Orde pertama dari interpolasi spline yang dapat didefinisikan dengan fungsi linier. Fungsi linier $s_{i}(x)$ dari garis yang melalui titik $x_{l}$ dan $x_{2}$,yaitu:

$$
\mu=\left(x-x_{1}\right) \cdot \frac{x_{2}-x_{1}}{x_{2}-x_{1}} \cdot\left(x_{2}-x_{1}\right)
$$

Sehingga persamaan dari spline linier adalah sebagai berikut (B. K. Lina, 2004): 


$$
s_{i}(x)=x_{i}+\mu_{i}\left(x_{i+1}-x_{i}\right)
$$

Keterangan:

$s_{i}(x)=$ Persamaan interpolasi spline.

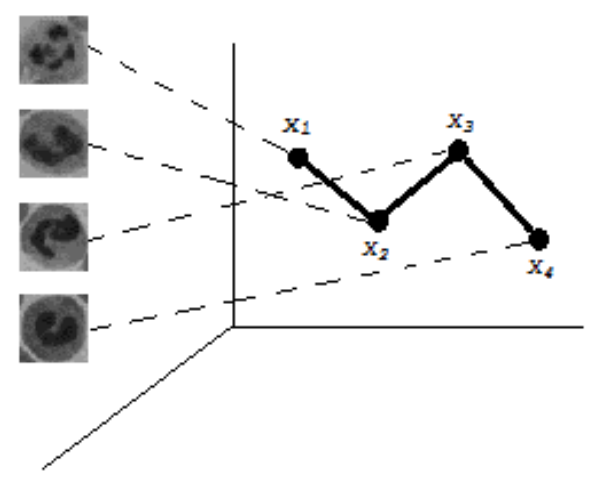

Sumber : (K. A. Lina, 2019)

Gambar 3. Spline Linier

\section{Spline Kuadratik}

Gambar 4 menunjukkan contoh interpolasi spline kuadratik dalam ruang Eigen. Orde kedua dari interpolasi spline, dimana tingkat kesalahannya lebih kecil dari linier. Persamaan spline kuadratik adalah sebagai berikut (Weisstein, 2017):

$$
s_{i}=\frac{t_{i+1}-t_{i}}{2\left(x_{i+1}-x_{i}\right)}\left(x_{i+1}-x_{i}\right)^{2}+t_{i}\left(x_{i+1}-x_{i}\right)+
$$

$x_{i}$

Dengan $t_{i}=s_{i}^{\prime}(x)$ dan ketetapan $s_{i}^{\prime}(0)=0$

$$
t_{i+1}=2 \frac{\left(x-x_{1}\right) \cdot\left(x_{2}-x_{1}\right)}{\left(x_{2}-x_{1}\right) \cdot\left(x_{2}-x_{1}\right)}-t_{i}
$$

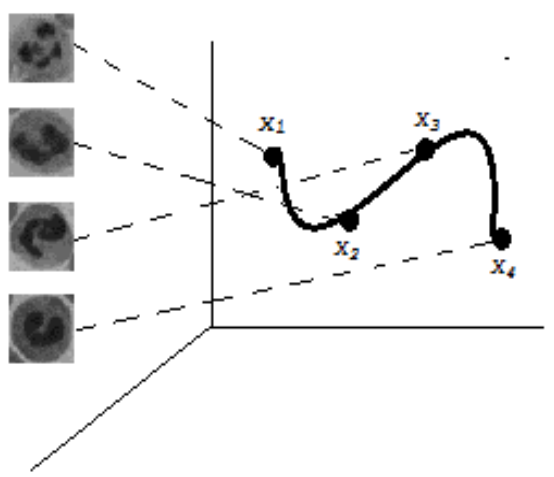

Sumber : (K. A. Lina, 2019)

Gambar 4. Spline Kuadratik

\section{Spline Kubik}

Gambar 5 menunjukkan contoh interpolasi spline kubik dalam ruang Eigen. Suatu potongan fungsi polinomial berderajat tiga (kubik) yg menghubungkan titik-titik data. Interpolasi spline kubik dapat ditentukan dengan persamaan :

$$
\begin{aligned}
& s_{i}(x)=\frac{v_{i}}{6\left(x_{i+1}-x_{i}\right)}\left(x_{i}-x_{i+1}\right)^{3}+\frac{v_{i+1}}{6\left(x_{i+1}-x_{i}\right)} \\
& \left(x_{i+1}-x_{i}\right)^{3}+\left[\frac{x_{i}}{x_{i+1}-x_{i}}-\frac{v_{i}\left(x_{i+1}-x_{i}\right)}{6}\right]\left(x_{i}-x_{i+1}\right) \\
& +\left[\frac{x_{i+1}}{x_{i+1}-x_{i}}-\frac{v_{i+1}\left(x_{i+1}-x_{i}\right)}{6}\right]\left(x_{i+1}-x_{i}\right) \ldots \ldots \ldots(13)
\end{aligned}
$$

Dengan $v_{i}=s_{i} "(x)$ dan ketetapan $s_{i} "(0)=0$

$$
v_{i+1}=3 \frac{\left(x-x_{1}\right) \cdot\left(x_{2}-x_{1}\right)}{\left(x_{2}-x_{1}\right) \cdot\left(x_{2}-x_{1}\right)}-v_{i}
$$

Setelah didapatkan persamaan untuk spline linier, spline kuadratik, dan spline kubik.Makanya langkah selanjutnya adalah memasukkan nilai $\mathrm{x}$, yang dimana $\mathrm{x}$ adalah interval.Disini karena menggunakan rotasi -15, -10, $-5,0,5,10,15$, dibagi menjadi 5 titik tiap intervalnya.

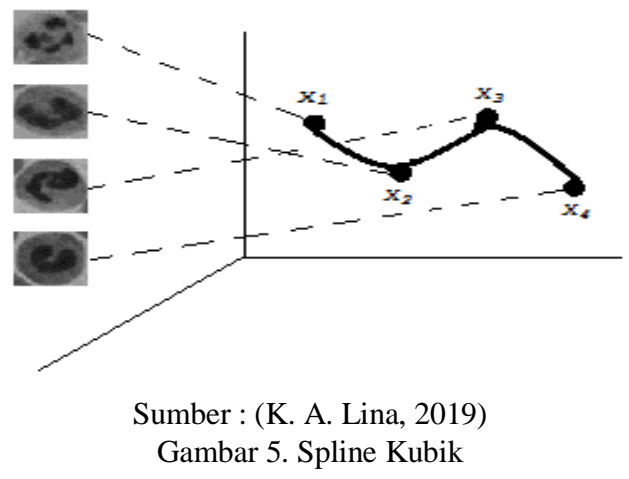

\section{Euclidean Distance}

Euclidean Distance merupakan metode pengukuran jarak antara dua buah vektor. Persamaan Euclidean distance secara umum adalah[1]:

$$
d=|x-p|=\sqrt{\sum_{i=1}^{j}\left(x_{i}-p_{i}\right)^{2}}
$$

Keterangan:

$$
\begin{aligned}
\boldsymbol{d}= & \text { Euclidean distance } \\
\boldsymbol{x}_{i}= & \text { Koordinat titik uji } \\
\boldsymbol{p}_{\boldsymbol{i}}= & \text { Koordinat titik latih } \\
\boldsymbol{j}= & \text { Banyaknya dimensi yang digunakan Setelah } \\
& \text { menghitung semua jarak titik uji, objek } \\
& \text { dikenali dengan kelas yang memiliki } \\
& \text { distance terpendek (nilai minimum) dalam } \\
& \text { ruang eigen. }
\end{aligned}
$$

\section{HASIL DAN PEMBAHASAN}

Pengujian dilakukan secara umum untuk melihat persentase keberhasilan hasil pengenalan sel darah putih dari aplikasi yang dibuat. 
Data yang digunakan berasal dari 261 buah foto sel darah yang berformat .bmp dengan rincian 33 untuk basofil, 20 untuk eosinofil, 70 untuk limfosit, 23 untuk monosit, dan 115 untuk neutrofil. Foto ini diambil dengan menggunakan kamera digital Olympus C5060 dengan F8, iso 400, mode Automatic dan berukuran 1600x1200 piksel yang dipasangkan pada sebuah mikroskop Nikon. Perbesaran yang digunakan adalah 1000x pada mikroskop dan perbesaran maksimal pada kamera.

Pada tahap pelatihan, citra yang digunakan adalah citra yang hanya terdapat sel darah putih (tidak terdapat gambar background). Pemisahan sel darah putih dari background dilakukan dengan menggunakan "Adobe Photoshop CS6" dan "FastStone Image Viewer" dengan cara merotasi citra, meresizenya menjadi ukuran 500 x 375 dan kemudian mengcrop nya pada bagian sel darah putih menjadi ukuran $50 \times 50$ pixel. Aplikasi ini dipilih karena penggunaannya yang mudah dan efisien.

Pada tahap uji citra mengalami beberapa proses sebelum diuji menggunakan metode Nearest Feature Line. Pengujian dilakukan dengan cara melakukan proses pelatihan dengan memasukan citra latih setelah dilakukan cropping 50x50 pixel. Kemudian dilakukan proses pelatihan dengan ekstraksi menggunakan metode Principal Component Analysis (PCA) yang sebelumnya ditentukan persentasi untuk proporsi kumulatifnya. Selanjutnya dilakukan pengenalan dengan metode Nearest Feature Line dengan Interpolasi Linier atau Spline dan kemudian dihitung jaraknya dengan metode Euclidean Distance. Tabel 1 hingga Tabel 12 menunjukkan hasil percobaan.

Tabel 1. Percobaan dengan Proporsi Kumulatif 70\%

\begin{tabular}{|c|c|c|c|c|c|}
\hline \multirow{2}{*}{$\begin{array}{c}\text { Interpolasi } \\
\text { Linier }\end{array}$} & \multicolumn{2}{|c|}{ Jumlah } & \multicolumn{2}{|c|}{ Hasil Pengenalan } & \multirow[b]{2}{*}{ Persentase } \\
\hline & $\begin{array}{l}\text { Citra } \\
\text { Latih }\end{array}$ & $\begin{array}{c}\text { Citra } \\
\text { Uji }\end{array}$ & Dikenali & $\begin{array}{c}\text { Tidak } \\
\text { Dikenali }\end{array}$ & \\
\hline Netrofil & 86 & 29 & 29 & 0 & 100 \\
\hline Eusinofil & 15 & 5 & 5 & 0 & 100 \\
\hline Basofil & 25 & 8 & 8 & 0 & 100 \\
\hline Limfosit & 53 & 17 & 16 & 1 & 94.1 \\
\hline Monosit & 17 & 6 & 4 & 2 & 66.7 \\
\hline
\end{tabular}

Tabel 2. Percobaan dengan Proporsi Kumulatif 70\%

\begin{tabular}{lccccc}
\hline Spline & Jumlah & \multicolumn{3}{c}{ Hasil Pengenalan } & \\
\cline { 2 - 5 } & $\begin{array}{l}\text { Citra } \\
\text { Latih }\end{array}$ & $\begin{array}{l}\text { Citra } \\
\text { Uji }\end{array}$ & Dikenali & $\begin{array}{l}\text { Tidak } \\
\text { Dikenali }\end{array}$ & Persentase \\
\hline Netrofil & 86 & 29 & 27 & 2 & 93.1 \\
\hline Eusinofil & 15 & 5 & 5 & 0 & 100 \\
\hline Basofil & 25 & 8 & 8 & 0 & 100 \\
\hline Limfosit & 53 & 17 & 16 & 1 & 94.1 \\
\hline Monosit & 17 & 6 & 5 & 1 & 83.3 \\
\hline
\end{tabular}
Sumber : (K. A. Lina, 2019)

Tabel 3. Percobaan dengan Proporsi Kumulatif 70\%

\begin{tabular}{lccccc}
\hline \multicolumn{1}{c}{$\begin{array}{c}\text { Spline } \\
\text { Kuadratik }\end{array}$} & \multicolumn{2}{c}{ Jumlah } & \multicolumn{2}{c}{ Hasil Pengenalan } & \\
\cline { 2 - 5 } & $\begin{array}{c}\text { Citra } \\
\text { Latih }\end{array}$ & $\begin{array}{c}\text { Citra } \\
\text { Uji }\end{array}$ & Dikenali & $\begin{array}{c}\text { Tidak } \\
\text { Dikenali }\end{array}$ & \\
\hline Netrofil & 86 & 29 & 0 & 29 & 0 \\
\hline Eusinofil & 15 & 5 & 0 & 5 & 0 \\
\hline Basofil & 25 & 8 & 0 & 8 & 0 \\
\hline Limfosit & 53 & 17 & 17 & 0 & 100 \\
\hline Monosit & 17 & 6 & 0 & 6 & 0 \\
\hline
\end{tabular}

Sumber : (K. A. Lina, 2019)

Tabel 4. Percobaan dengan Proporsi Kumulatif 70\%

\begin{tabular}{lccccc}
\hline \multirow{2}{*}{$\begin{array}{c}\text { Spline } \\
\text { Kubik }\end{array}$} & \multicolumn{2}{c}{ Jumlah } & \multicolumn{2}{c}{ Hasil Pengenalan } & \\
\cline { 2 - 5 } & $\begin{array}{c}\text { Citra } \\
\text { Latih }\end{array}$ & $\begin{array}{c}\text { Citra } \\
\text { Uji }\end{array}$ & Dikenali & $\begin{array}{c}\text { Tidak } \\
\text { Dikenali }\end{array}$ & Persentase \\
\hline Netrofil & 86 & 29 & 29 & 0 & 100 \\
\hline Eusinofil & 15 & 5 & 0 & 5 & 0 \\
\hline Basofil & 25 & 8 & 0 & 8 & 0 \\
\hline Limfosit & 53 & 17 & 0 & 17 & 0 \\
\hline Monosit & 17 & 6 & 0 & 6 & 0 \\
\hline \multicolumn{5}{c}{ Sumber : (K. A. Lina, 2019) }
\end{tabular}

Tabel 5. Percobaan dengan Proporsi Kumulatif $80 \%$

\begin{tabular}{lccccc}
\hline & \multicolumn{3}{c}{ Jumlah } & \multicolumn{3}{c}{ Hasil Pengenalan } & Persentase \\
\cline { 2 - 5 } & $\begin{array}{c}\text { Citra } \\
\text { Latih }\end{array}$ & $\begin{array}{l}\text { Citra } \\
\text { Uji }\end{array}$ & Dikenali & $\begin{array}{l}\text { Tidak } \\
\text { Dikenali }\end{array}$ & \\
\hline Netrofil & 86 & 29 & 29 & 0 & 100 \\
\hline Eusinofil & 15 & 5 & 5 & 0 & 100 \\
\hline Basofil & 25 & 8 & 8 & 0 & 100 \\
\hline Limfosit & 53 & 17 & 17 & 0 & 100 \\
\hline Monosit & 17 & 6 & 6 & 0 & 100 \\
\hline \multicolumn{5}{c}{ Sumber : (K. A. Lina, 2019) }
\end{tabular}

Tabel 6. Percobaan dengan Proporsi Kumulatif $80 \%$

\begin{tabular}{lccccc}
\hline \multirow{2}{*}{$\begin{array}{c}\text { Spline } \\
\text { Linier }\end{array}$} & \multicolumn{2}{c}{ Jumlah } & \multicolumn{2}{c}{ Hasil Pengenalan } & Pitra \\
\cline { 2 - 5 } Latih & $\begin{array}{c}\text { Citra } \\
\text { Uji }\end{array}$ & Dikenali & $\begin{array}{c}\text { Tidak } \\
\text { Dikenali }\end{array}$ & Persentase \\
\hline Netrofil & 86 & 29 & 29 & 0 & 100 \\
\hline Eusinofil & 15 & 5 & 5 & 0 & 100 \\
\hline Basofil & 25 & 8 & 8 & 0 & 100 \\
\hline Limfosit & 53 & 17 & 16 & 1 & 94.1 \\
\hline Monosit & 17 & 6 & 6 & 0 & 100 \\
\hline \multicolumn{5}{c}{ Sumber : (K. A. Lina, 2019) }
\end{tabular}

Tabel 7. Percobaan dengan Proporsi Kumulatif $80 \%$

\begin{tabular}{lccccc}
\hline \multirow{2}{*}{$\begin{array}{c}\text { Spline } \\
\text { Kuadratik }\end{array}$} & \multicolumn{2}{c}{ Jumlah } & \multicolumn{2}{c}{ Hasil Pengenalan } & \\
& $\begin{array}{l}\text { Citra } \\
\text { Latih }\end{array}$ & $\begin{array}{c}\text { Citra } \\
\text { Uji }\end{array}$ & Dikenali & $\begin{array}{c}\text { Tidak } \\
\text { Dikenali }\end{array}$ & Persentase \\
\hline Netrofil & 86 & 29 & 29 & 0 & 100 \\
\hline Eusinofil & 15 & 5 & 0 & 5 & 0 \\
\hline Basofil & 25 & 8 & 0 & 8 & 0 \\
\hline Limfosit & 53 & 17 & 0 & 17 & 0 \\
\hline Monosit & 17 & 6 & 0 & 6 & 0 \\
\hline \multicolumn{6}{c}{ Sumber : (K. A. Lina, 2019) }
\end{tabular}


Tabel 8. Percobaan dengan Proporsi Kumulatif $80 \%$

\begin{tabular}{lccccc}
\hline \multirow{2}{*}{$\begin{array}{l}\text { Spline } \\
\text { Kubik }\end{array}$} & \multicolumn{2}{c}{ Jumlah } & \multicolumn{2}{c}{ Hasil Pengenalan } & \\
\cline { 2 - 5 } & $\begin{array}{c}\text { Citra } \\
\text { Latih }\end{array}$ & $\begin{array}{c}\text { Citra } \\
\text { Uji }\end{array}$ & Dikenali & $\begin{array}{l}\text { Tidak } \\
\text { Dikenali }\end{array}$ & \\
\hline Netrofil & 86 & 29 & 29 & 0 & 100 \\
\hline Eusinofil & 15 & 5 & 0 & 5 & 0 \\
\hline Basofil & 25 & 8 & 0 & 8 & 0 \\
\hline Limfosit & 53 & 17 & 0 & 17 & 0 \\
\hline Monosit & 17 & 6 & 0 & 6 & 0 \\
\hline \multicolumn{6}{c}{ Sumber : (K. A. Lina, 2019) }
\end{tabular}

Tabel 9. Percobaan dengan Proporsi Kumulatif 90\%

\begin{tabular}{|c|c|c|c|c|c|}
\hline \multirow{2}{*}{$\begin{array}{l}\text { Interpolasi } \\
\text { Linier }\end{array}$} & \multicolumn{2}{|c|}{ Jumlah } & \multicolumn{2}{|c|}{ Hasil Pengenalan } & \multirow[b]{2}{*}{ Persentase } \\
\hline & $\begin{array}{l}\text { Citra } \\
\text { Latih }\end{array}$ & $\begin{array}{l}\text { Citra } \\
\text { Uji }\end{array}$ & Dikenali & $\begin{array}{l}\text { Tidak } \\
\text { Dikenali }\end{array}$ & \\
\hline Netrofil & 86 & 29 & 29 & 0 & 100 \\
\hline Eusinofil & 15 & 5 & 5 & 0 & 100 \\
\hline Basofil & 25 & 8 & 8 & 0 & 100 \\
\hline Limfosit & 53 & 17 & 16 & 1 & 94.1 \\
\hline Monosit & 17 & 6 & 6 & 0 & 100 \\
\hline
\end{tabular}

Tabel 10. Percobaan dengan Proporsi Kumulatif 90\%

\begin{tabular}{lccccc}
\hline \multirow{2}{*}{$\begin{array}{l}\text { Spline } \\
\text { Linier }\end{array}$} & \multicolumn{2}{c}{ Jumlah } & \multicolumn{3}{c}{ Hasil Pengenalan } \\
\cline { 2 - 5 } & $\begin{array}{l}\text { Citra } \\
\text { Latih }\end{array}$ & $\begin{array}{l}\text { Citra } \\
\text { Uji }\end{array}$ & Dikenali & $\begin{array}{l}\text { Tidak } \\
\text { Dikenali }\end{array}$ & \\
\hline Netrofil & 86 & 29 & 29 & 1 & 96.5 \\
\hline Eusinofil & 15 & 5 & 5 & 0 & 100 \\
\hline Basofil & 25 & 8 & 8 & 0 & 100 \\
\hline Limfosit & 53 & 17 & 16 & 1 & 94.1 \\
\hline Monosit & 17 & 6 & 6 & 0 & 100 \\
\hline \multicolumn{5}{c}{ Sumber : (K. A. Lina, 2019) }
\end{tabular}

Tabel 11. Percobaan dengan Proporsi Kumulatif 90\%

\begin{tabular}{cccccc}
\hline $\begin{array}{c}\text { Spline } \\
\text { Kuadratik }\end{array}$ & \multicolumn{2}{c}{ Jumlah } & \multicolumn{2}{c}{ Hasil Pengenalan } & \\
& $\begin{array}{c}\text { Citra } \\
\text { Latih }\end{array}$ & $\begin{array}{c}\text { Citra } \\
\text { Uji }\end{array}$ & Dikenali & $\begin{array}{c}\text { Tidak } \\
\text { Dikenali }\end{array}$ & Persentase \\
\hline Netrofil & 86 & 29 & 0 & 29 & 0 \\
\hline Eusinofil & 15 & 5 & 0 & 5 & 0 \\
\hline Basofil & 25 & 8 & 0 & 8 & 0 \\
\hline Limfosit & 53 & 17 & 0 & 17 & 0 \\
\hline Monosit & 17 & 6 & 6 & 0 & 100 \\
\hline \multicolumn{6}{c}{ Sumber : (K. A. Lina, 2019) }
\end{tabular}

Tabel 12. Percobaan dengan Proporsi Kumulatif 90\%

\begin{tabular}{|c|c|c|c|c|c|}
\hline \multirow{2}{*}{$\begin{array}{l}\text { Spline } \\
\text { Kubik }\end{array}$} & \multicolumn{2}{|c|}{ Jumlah } & \multicolumn{2}{|c|}{ Hasil Pengenalan } & \multirow[b]{2}{*}{ Persentase } \\
\hline & $\begin{array}{l}\text { Citra } \\
\text { Latih }\end{array}$ & $\begin{array}{l}\text { Citra } \\
\text { Uji }\end{array}$ & Dikenali & $\begin{array}{l}\text { Tidak } \\
\text { Dikenali }\end{array}$ & \\
\hline Netrofil & 86 & 29 & 0 & 29 & 0 \\
\hline Eusinofil & 15 & 5 & 0 & 5 & 0 \\
\hline Basofil & 25 & 8 & 0 & 8 & 0 \\
\hline Limfosit & 53 & 17 & 0 & 17 & 0 \\
\hline Monosit & 17 & 6 & 6 & 0 & 100 \\
\hline
\end{tabular}

Hasil pengujian pengenalan sel darah putih menggunakan metode Nearest Feature Line dengan berbagai teknik interpolasi dan variasi parameter persentase proporsi kumulatif pada metode PCA menunjukkan bahwa metode Nearest
Feature Line memiliki persentasi keberhasilan yang baik dalam pengenalan pada Interpolasi Linier dan Interpolasi Spline Linier, akan tetapi masih sangat buruk pada Interpolasi Spline Kuadratik dan Kubik dikarenakan hasil dari persamaan Spline Kuadratik dan Kubik memiliki hasil yang sangat besar, sehingga ketika di bandingkan vektor menggunakan Euclidean Distance mendapatkan hasil yang sangat jauh.

\section{KESIMPULAN}

Kesimpulan yang dapat diberikan adalah metode Nearest Feature Line memiliki tingkat keberhasilan yang baik dalam pengenalan pada Interpolasi Linier dan Interpolasi Spline Linier, akan tetapi masih sangat buruk pada Interpolasi Spline Kuadratik dan Kubik dikarenakan hasil dari persamaan Spline Kuadratik dan Kubik memiliki hasil yang sangat besar, sehingga ketika di bandingkan vektor menggunakan Euclidean Distance mendapatkan jarak titik yang relatif besar. Metode Spline Kuadratik dan Kubik tidak cocok digunakan sebagai penentu garis ciri dikarenakan hasil dari perhitungan persamaan yang didapat terlalu besar. Data pada penelitian ini menggunakan citra RGB sehingga perbedaan warna pada data latih dan data uji sangat berpengaruh pada hasil pengenalannya.

\section{DAFTAR PUSTAKA}

Chapra, S. C. (2005). Applied Numerical Methods with MATLAB for Engineers and Scientists. The McGraw-Hill Companies, Inc.

Hoffbrand, A.V Pettit, J.E and Moss, P. A. H. (2008). HEMATOLOGI (Lyana Setiawan (ed.); Edisi 4). Kapita Selekta.

Kiernan, J. . (1999). Histological \& Histochemical Methods (Oxford).

Kusumoputro, B. (2003). Garis Ciri Pada Metode Perhitungan Jarak Terpendek Dalam Ruang Eigen. Universitas Stuttgart, 7(1), 1-10.

Li, S. Z. (1999). S. Z. Li and Juwei Lu, "Face recognition using the nearest feature line method," in IEEE Transactions on Neural Networks, vol. 10, no. 2, pp. 439-443, March 1999.

Lina, B. K. (2004). Sistem Pengenalan Wajah 3-D Menggunakan Garis Ciri pada Metode Perhitungan Jarak Terpendek dalam Ruang Eigen, Jurnal Makara Seri Sains. Universitas Indonesia, 7(1), 1-6.

Lina, K. A. (2019). KOMPARASI METODE INTERPOLASI UNTUK SISTEM PENGENALAN SEL DARAH PUTIH.

Sani, A. (2018). Penerapan Metode K-Means Clustering Pada Perusahaan. Jurnal Ilmiah Teknologi Informasi, 353, 1-7.

Weisstein, E. W. (2017). Distance. https:// mathworld.wolfram.com/Distance.html 